\title{
DIAKRONIKA
}

Vol. 18 No. 2 Th. 2018 p: 138-151

ISSN: 1411-1764 (Print) | 2620-9446 (Online)

http://diakronika.ppj.unp.ac.id

\section{Kendala Yang Dihadapi Mahasiswa Jurusan Sejarah Dalam Menulis Proposal Skripsi}

\author{
Aisiah, Firza \\ aisiah.unp@gmail.com; firza1814@gmail.com \\ Universitas Negeri Padang
}

\begin{abstract}
Students generally experience obstacles in writing thesis research proposals. The research findings indicate that the problems in writing a thesis proposal by students include; find research ideas, look for literature and empirical data in the field as well as technical constraints related to aspects of writing relating to structure (systematics) and rules for using scientific and standard Indonesian languages. The specific problem of writing proposal research types, among others, relates to the development of a framework that describes the paradigm of relationships between variables, determining the design of experimental designs, how to determine samples and analyze data using formulas and statistics. Constraints on PTK proposal writing, among others, relate to the determination of research design in the form of the PTK cycle including the activities carried out in each cycle, determining indicators of success, data collection and data analysis. While writing a proposal for the type of $R$ $\& D$ research students face constraints related to determining product specifications that are attractive and truly needed by teachers and students, relevant literature, writing framework, selection of development models, and product trial designs. The study of this study describes the obstacles faced by students in writing research proposals for history education thesis. The aim is to identify common obstacles experienced by students in writing thesis proposals, including specific obstacles to writing experimental research proposals, CAR and R\&D. Data on the constraints of thesis proposal writing are collected by interviewing students, examining their thesis proposals and examining students' written reports about the perceived constraints when writing a thesis proposal. The source of research data comes from students, thesis documents and experience reports writing thesis proposals. This data was analyzed descriptively qualitatively.
\end{abstract}

Keywords : thesis proposal, experiment, PTK, R\&D, research, constraints

\begin{abstract}
Abstrak
Mahasiswa umumnya mengalami kendala dalam menulis proposal penelitian skripsi. Temuan penelitian menunjukkan bahwa kendala menulis proposal skripsi oleh mahasiswa antara lain; menemukan ide penelitian, mencari literatur dan data empiris di lapangan serta kendala teknis terkait aspek penulisan berkenaan dengan struktur (sistematika) dan kaidah penggunaan bahasa ilmiah maupun bahasa Indonesia baku. Kendala khsusus penulisan proposal jenis penelitian eksperimen, antara lain berkenaan dengan pengembangan kerangka pikir yang menggambarkan paradigma
\end{abstract}


hubungan antar variabel, penentuan rancangn desain eksperimen, cara menentukan sampel dan menganalisis data menggunakan rumus-rumus statistik. Kendala penulisan proposal PTK, antar lain berkenaan dengan penentuan desain penelitian berupa siklus PTK termasuk kegiatan yang dilakukan pada tiap siklus, penentuan indikator keberhasilan, pengumpulan data dan analisis data. Sementara dalam menulis proposal jenis penelitian $R \& D$ mahasiswa menghadapi kendala terkait penentuan spesifikasi produk yang menarik dan benar-benar dibutuhkan oleh guru maupun peserta didik, literatur yang relevan, penulisan kerangka pikir, pemilihan model pengembangan, dan desain uji coba produk. Kajian penelitian ini memaparkan kendala-kendala yang dihadapi mahasiswa dalam menulis proposal penelitian skripsi pendidikan sejarah.Tujuannya untuk mengidentifikasi kendala umum yang dialami mahasiswa dalam menulis proposal skripsi, termasuk kendala khusus penulisan proposal penelitian eksperimen, PTK dan R\&D. Data tentang kendala penulisan proposal skripsi dikumpulkan dengan cara mewawancarai mahasiswa, memeriksa proposal skripsinya dan mencermati laporan tertulis mahasiswa tentang kendala yang dirasakan saat menulis proposal skripsi. Sumber data penelitian berasal dari mahasiswa, dokumen skripsi dan laporan pengalaman menulis menulis proposal skripsi. Data ini dianalisis secara deskriptif kualitatif.

Kata kunci : proposal skripsi, eksperimen, PTK, R\&D, penelitian, kendala

\section{Pendahuluan}

Penyelesaian studi di perguruan tinggi umumnya mempersyaratkan mahasiswa harus menyelesaikan Tugas Akhir (TA) atau yang biasa disebut dengan skripsi untuk program pendidikan sarjana, tesis untuk program pendidikan pascasarjana dan disertasi untuk program pendidikan doktor. Penyusunan skripsi adalah fase terakhir yang dilalui oleh mahasiswa pada program pendidikan sarjana. Skripsi disusun sebagai syarat untuk mendapatkan gelar sarjana sesuai dengan program studi yang ditekuni. Melalui penyusunan skripsi mahasiswa dituntut melakukan suatu kegiatan penelitian yang diawali dengan penulisan proposal penelitian. Umumnya mahasiswa baru bisa mengambil mata kuliah skripsi jika mahasiswa tersebut telah menyelesaikan sejumlah mata kuliah ( \pm 110 SKS) dengan Indeks Prestasi Kumulatif (IPK) minimal 2,00 tanpa ada nilai $\mathrm{E}$ dan telah mendapatkan rekomendasi dari Penasehat Akademik.

Setelah semua persyaratan tersebut dipenuhi, mahasiswa selanjutnya akan menulis atau menyusun proposal penelitian sesuai dengan minatnya dan diarahkan oleh dosen pembimbing skripsi. Proposal penelitian skripsi yang baik pada prinsipnya mencakup beberapa bab dan subbab. Paling tidak ada tiga bab yang menjadi bagian penting proposal penelitian. Bab tersebut mencakup; 1) bab pendahuluan, 2) bab kajian teori ataukerangka konseptual, 
dan 3) bab metode penelitian, serta informasi daftar pustaka.Masing-masing bab berisi rincian sub-sub bab yang disusun secara sistematis.Pada bab pendahuluan secara garis besar terdiri dari subbab; latar belakang masalah, identifikasi dan pembatasan masalah, rumusan masalah, tujuan penelitian dan manfaat penelitian. Bab kajian teori atau kerangka konseptual biasanya berisi sub-subbab yang mengkaji aspek-aspek teoretis dari topik penelitian yang ditulis. Bab metode umumnya berisi subbab; jenis penelitian, sumber data, teknik dan instrumen pengumpulan data serta teknik analisis data.Bagian terakhir proposal penelitian adalah daftar pustaka. Proses penulisan proposal skripsi, melakukan penelitianhingga penulisan naskah skripsi dan ujian skripsi biasanya diselesaikan mahasiswa dalam jangka waktu rata-rata satu atau dua semester. Mahasiswa diharapkan mampu menyelesaikan studi dengan waktu yang ideal yaitu 7-8 semester atau 3,5 s.d 4 tahun.

Namun sayang, realitanya tidak banyak mahasiswa dapat memenuhi standar tesebut. Tidak sedikit mahasiswa menyelesaikan studinya lebih dari waktu 4 tahun, bahkan ada yang menghabiskan waktu 10 s.d 12 semester. Kondisi ini tentu perlu ditanggapi dengan serius baik oleh mahasiswa, dosen pembimbing maupunpengelola jurusan. Salah satu upaya yang bisa dilakukan adalah dengan cara menelusuri penyebab mengapa mahasiwa tidak mampu mencapai standar penyelesaian studi yang ideal tersebut. Penelitian ini berfokus pada identifikasi kendala yang dihadapi mahasiswa dalam proses penyusunan skripsi, khususnya kendala pada tahap penulisan proposal penelitian. Jika hal ini tidak dikaji, tentu sulit diidentifikasi berdasarkan bukti empiris kendala penulisan proposal skripsi oleh mahasiswa. Dampak lanjutannya dapat berakibat pada hilangnya motivasi untuk menyelesaikan tugas akhir.

Informasi dan penjelasan diatas menunjukkan pentingnya kajian penelitian ini dilakukan guna memetakan dan menganalisis kendala penulisanproposal skripsi mahasiswa, khususnya pada penulisan proposal skripsi di bidang pendidikan sejarah. Dengan mengetahui kendala-kendala yang sering dialami oleh mahasiswa, Harapannya apapun jenis kendala yang dialami mahasiswa saat menulis proposal skripsi dapat diatasi dengan baik sehingga tidak lagi muncul kendala yang sama dan berulang terus dari waktu ke waktu. Untuk itu kajian penelitian ini berfokus untuk identifikasi ragam kendala penulisan proposal penelitian skripsi serta penyebabdancara mengatasinya.

Secara umum definisi proposal dalam KBBI (2008) (Kamus Besar Bahasa Indonesia) merujuk pada rencana yang dituangkan dalam bentuk rancangan kerja. Jenis proposal dapat dibedakan menjadi dua, yakni proposal kegiatan 
dan proposal penelitian. Ada banyak jenis proposal penelitian, salah satunya proposal penelitian sebagai prasarat penyelesaian studi di lembaga pendidikan tinggi. Di Indonesia dikenal tiga jenis proposal penelitian dalam upaya penyelesaian studi, yakni proposal skripsi, proposal tesis dan proposal disertasi. Ketiga jenis proposal penelitian ini disesuaikan dengan jenis dan jenjang program pendidikan yang diambil oleh mahasiswa. Proposal penelitian skripsi untuk program pendidikan sarjana (S1), proposal penelitian tesis untuk program pascasarjana (S2) dan proposal penelitian disertasi untuk program doktor (\$3). Artikel ini khusus mengkaji ragam kendala penulisan proposal penelitian skripsi pada Program Pendidikan Sarjana, khususnya Program Studi Pendidikan Sejarah di Fakultas IImu Sosial Universitas Negeri Padang.

Skripsi adalah karya ilmiah yang ditulis mahasiswa untuk menyelesaikan program pendidikan sarjana (strata satu) pada suatu bidang studi tertentu. Skripsi merupakan karya puncak atau karya akhir yang memberi indikator pada pemahaman atau ketercapaian penguasaan disipilin ilmu oleh mahasiswa yang bersangkutan (Muslich, 2010). Pengertian skripsi menurut Hadi (2001) adalah karya ilmiah berupa karya tulis yang dibuat berdasarkan pengetahuan-pengetahuan khusus dan fakta-fakta yang jelas. Fakta-fakta tersebut kemudian dirangkai menjadi pemecahan masalah yang bersifat umum dengan pembuktian yang benar. Skripsi merupakan penyusunan tugas akhir mahasiswa dalam suatu proses pembelajaran yang digunakan untuk evaluasi kegiatan belajar mengajar pada suatu institusi baik perguruan tinggi, universitas, sekolah tinggi maupun institut. Tujuan penulisan skripsi adalah untuk memberikan pengalaman belajar kepada mahasiswa dalam memecahkan suatu permasalahan secara ilmiah dengan cara melakukan penelitian sendiri, menganalisis dan menarik kesimpulan (Darmono \& Hasan, 2002) serta membuat laporan tertulis sebagai bentuk pertanggungjawaban akademis dalam upaya penyelesaian studi. Pengalaman ini diawali dengan penulisan proposal penelitian.

Dengan merujuk pada pengertian proposal menurut $\mathrm{KBBI}$ di atas dapat dipahami bahwa proposal skripsi adalah rancangan kerja untuk melakukan penelitian pada suatu bidang studi tertentu dalam rangka menghasilkan karya tulis ilmiah sebagai prasyarat penyelesaian studi di perguruan tinggi pada program pendidikan sarjana. (Tan et al., 2017) Sherina Mohd Sidik, 2005: 30 menjelaskan bahwa dalam penulisan proposal penelitian skripsi paling tidak mesti menjawab tiga pertanyaan dasar berikut; yakni 1) apa yang ingin dikerjakan atau diteliti, 2) apa alasannya (latar belakang dan urgensi mengapa ingin mengerjakan atau meneliti hal tersebut) dan bagaimana cara menindaklanjutinya. Komponen utama sebuah proposal penelitian skripsi 
yang ditulis mahasiswa minimal mencakup; judul, pendahuluan, kajian literatur atau kerangka teori,metode penelitian dan daftar pustaka. Artinya apapun jenis penelitian yang dilakukan lima komponen utama ini harus ada dan ditulis dalam proposal penelitian. Variasi sistematika penulisan bab dan subbab proposal skripsi disesuaikan dengan jenis penelitian yang dilakukan. Bentuk sistematika penulisan proposal skripsi yang baku biasanya ditetapkan oleh tiap lembaga pendidikan melalui gaya selingkung yang disepakati bersama. Namun demikian pada prinsipnya selalu ada unsur utama yang berlaku umum dalam setiap penulisan proposal skripsi.

\begin{tabular}{|c|c|c|c|c|}
\hline $\begin{array}{l}\text { Proposal } \\
\text { Penelitian }\end{array}$ & $\begin{array}{c}\text { Penelitian } \\
\text { Kuantitatif } \\
\text { (Eksperimen) }\end{array}$ & $\begin{array}{l}\text { Penelitian } \\
\text { Kualitatif }\end{array}$ & $\begin{array}{l}\text { Kajian (Studi) } \\
\text { Pustaka }\end{array}$ & $\begin{array}{c}\text { Kerja } \\
\text { Pengembangan } \\
\text { (R\&D) }\end{array}$ \\
\hline Bagian Awal & $\begin{array}{l}\text { Halaman sampul } \\
\text { Daftar isi }\end{array}$ & $\begin{array}{l}\text { Halaman sampul } \\
\text { Daftar isi }\end{array}$ & $\begin{array}{l}\text { Halaman sampul } \\
\text { Daftar isi }\end{array}$ & $\begin{array}{l}\text { Halaman } \\
\text { sampul } \\
\text { Daftar isi }\end{array}$ \\
\hline & $\begin{array}{l}\text { BAB I } \\
\text { PENDAHULUAN } \\
\text { A. Latar belakang } \\
\text { masalah } \\
\text { B. Rumusan } \\
\text { Masalah } \\
\text { C. Tujuan } \\
\text { Penelitian } \\
\text { D. Hipotesis } \\
\text { penelitian } \\
\text { E. Kegunaan } \\
\text { penelitian } \\
\text { F. Asumsi } \\
\text { penelitian }\end{array}$ & $\begin{array}{l}\text { Ada } 3 \text { alternatif: } \\
\text { Alternatif } 1 \\
\text { BAB I } \\
\text { PENDAHULUAN } \\
\text { A. Konteks } \\
\text { penelitian } \\
\text { atau latar } \\
\text { belakang } \\
\text { B. Fokus } \\
\text { penelitian } \\
\text { atau rumusan } \\
\text { masalah } \\
\text { C. Tujuan } \\
\text { penelitian }\end{array}$ & $\begin{array}{l}\text { BAB I } \\
\text { PENDAHULUAN } \\
\text { A. Latar } \\
\text { belakang } \\
\text { masalah } \\
\text { B. Rumusan } \\
\text { Masalah } \\
\text { C. Tujuan } \\
\text { penelitian } \\
\text { D. Kegunaan } \\
\text { kajian } \\
\text { E. Metode } \\
\text { kajian } \\
\text { F. Definisi istilah }\end{array}$ & $\begin{array}{l}\text { BAB I } \\
\text { PENDAHULUA } \\
\mathrm{N} \\
\text { A. Latar } \\
\text { belakang } \\
\text { masalah } \\
\text { B. Rumusan } \\
\text { Masalah } \\
\text { C. Tujuan } \\
\text { penelitian } \\
\text { D. Spesifikasi } \\
\text { produk yang } \\
\text { diharapkan } \\
\text { E. Pentingnya }\end{array}$ \\
\hline Bagian Inti & $\begin{array}{l}\text { G. Ruang lingkup } \\
\text { dan } \\
\text { keterbatasan } \\
\text { penelitian }\end{array}$ & $\begin{array}{l}\text { D. Landasan } \\
\text { teori } \\
\text { E. Kegunaan } \\
\text { penelitian }\end{array}$ & & $\begin{array}{l}\text { pengembang } \\
\text { an } \\
\text { F. Asumsi dan } \\
\text { keterbatasan } \\
\text { pengembang } \\
\text { an }\end{array}$ \\
\hline & 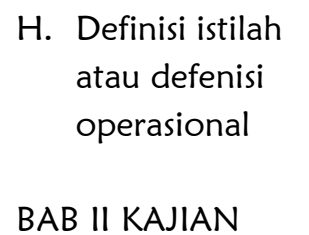 & $\begin{array}{l}\text { BAB II METODE } \\
\text { PENELITIAN } \\
\text { A. Pendekatan } \\
\quad \text { dan jenis } \\
\text { penelitian }\end{array}$ & & $\begin{array}{l}\text { G. Definisi } \\
\text { istilah } \\
\text { H. Sistematika } \\
\text { penulisan }\end{array}$ \\
\hline & $\begin{array}{l}\text { PUSTAKA } \\
\text { A. ............ } \\
\text { B. .......... } \\
\text { BAB III METODE }\end{array}$ & $\begin{array}{l}\text { B. Kehadiran } \\
\text { peneliti } \\
\text { C. Lokasi } \\
\text { penelitian }\end{array}$ & & $\begin{array}{l}\text { BAB } \| \text { KAJIAN } \\
\text { PUSTAKA } \\
\text { A. ...... } \\
\text { B. ....... }\end{array}$ \\
\hline
\end{tabular}


Aisiah, Firza

Kendala Yang Dihadapi Mahasiswa Jurusan Sejarah Dalam Menulis Proposal Skripsi

\begin{tabular}{|c|c|c|}
\hline PENELITIAN & D. Sumber data & \\
\hline A. Rancangan & E. Prosedur & B AB III \\
\hline penelitian & pengumpulan & METODE \\
\hline B. Populasi dan & data & PENGEMBANG \\
\hline sampel & F. Analisis data & AN \\
\hline $\begin{array}{l}\text { C. Instrumen } \\
\text { penelitian }\end{array}$ & $\begin{array}{l}\text { G. Tahap-tahap } \\
\text { penelitian }\end{array}$ & $\begin{array}{l}\text { A. Model } \\
\text { pengembaga }\end{array}$ \\
\hline D. Pengumpulan & & $\mathrm{n}$ \\
\hline data & Alternatif 2 & B. Prosedur \\
\hline E. Analisis data & BAB I & pengembang \\
\hline & PENDAHULUAN & an \\
\hline & A. Konteks & C. Uji coba \\
\hline & penelitian & produk \\
\hline & atau latar & 1. Desain uji \\
\hline & belakang & coba \\
\hline & B. Fokus & 2.Subjek uji \\
\hline & penelitian & coba \\
\hline & atau rumusan & 3.Jenis data \\
\hline & masalah & 4.Instrument \\
\hline & C. Tujuan & pengumpul \\
\hline & penelitian & an data \\
\hline & D. Kegunaan & 5.Teknik \\
\hline & penelitian & analisis \\
\hline & BAB \| KAJIAN & data \\
\hline & PUSTAKA & \\
\hline & BAB III METODE & \\
\hline & PENELITIAN & \\
\hline
\end{tabular}

Alternatif 3

BAB I

PENDAHULUAN

A. Konteks

penelitian

atau latar

belakang

B. Fokus

penelitian

atau rumusan

masalah

C. Tujuan

penelitian

D. Kegunaan

penelitian

E. Metode

penelitian

F. Landasan

teori

Tabel 1. Sistematikan Penulisan Proposal berbagai Jenis Penelitian 
Sumber : Disarikan dari Ali Saukah, dkk. Pedoman Penulisan Karya ilmiah Universitas Negeri Malang. hal 7-41.

Menulis proposal penelitian skripsi juga bukan pekerjaan dan perkara yang mudah, bahkan tidak gampang mengartikulasikan sebuah ide baru yang belum begitu dipahami dengan baik oleh mahasiswa, termasuk memunculkan persoalan problematis yang perlu ditemukan solusinya. Jika terlalu banyak masalah yang ditulis dalam proposal skripsi pada akhirnya malah tidak terpecahkan. Kondisi ini akan menjadi lebih baik jika dipilih satu set masalah yang dari awal sudah diyakini ada datanya dan bisa diteliti (Oruc, 2012). Mahasiswa perlu mengembangkan rencana kerja penulisan proposal penelitian skripsi. Menulis proposal penelitian membutuhkan waktu dan konsentrasi tingkat tinggi. Pra penulisan proposal mencakup pengumpulan informasi dan perencanaan rancangan penelitian. Kendala yang dihadapi biasanya berkenaan dengan ketersediaan sumber bacaan (Oruc, 2012) yang relevan sebab penulisan proposal juga bergantung pada ketersediaan referensi. Kendala yang sering dihadapi mahasiswa adalah menuangkan ide kedalam bahasa ilmiah dan kesulitan dengan standar tata tulis ilmiah (Muta'ali, Kinasih, \& Sumini, 2012)

Selain kendala mengenai ketersediaan referensi juga terdapat kendala lain, yakni lemahnya pemahaman mahasiswa tentang metodologi penelitian yang harus dituangkan dalam penulisan proposal penelitian skripsi. Kurangnya pengetahuan dan pemahaman yang mendalam mengenai selukbeluk penulisan proposal skripsi tidak jarang mengakibatkan hilangnya semangat dan motivasi mahasiswa untukmenulis proposal skripsi. Motivasi menulis proposal skripsi menjadi pilar utama yang akan membangkitkan semangat dan mengarahkan pola kerja mahasiswa dalam menulis. Kendala lain yang juga menjadi penghalang mahasiswa menulis proposal skripsi berkenaan dengan faktor pembimbing. Masalah muncul manakala mahasiswa dihantui rasa takut untuk menemui dan berkonsultasi dengan dosen pembimbing. Kendala lainnya berkenaan dengan proses bimbingan penulisan proposal penelitian. Proses bimbingan sebagian besar juga ditentukan oleh hubungan emosional antara mahasiswa dengan dosen pembimbing. Proses bimbingan atau pola komunikasi yang tidak lancar dengan pembimbing kadang juga memicu munculnya berbagai gangguan emosional bagi mahasiswa.Dalam situasi tertentu bahkan diperlukan perhatian khusus kepada mahasiswa demi kelanjutan penulisan skripsinya.

\section{Metode}

Kajian penelitian ini menggunakan pendekatan deskriptif kualitatif. Penelitian dilakukan di Program Studi Pendidikan Sejarah Fakultas IImu Sosial 
Universitas Negeri Padang. Fokus penelitian adalah menganalisis lebih dalam kesulitan mahasiswa dalam menulis proposal penelitian untuk skripsi. Sumber data berasal dari dokumen-dokumen proposal skripsi yang telah ditulis oleh mahasiswa. Dengan demikian data penelitian berasal dari dokumen proposal skripsi mahasiswa, terutama mahasiswa yang mengambil mata kuliah metode penelitian pendidikan pada semester Januari-Juni tahun akademik 2017/2018. Mahasiswa yang mengambil mata kuliah ini adalah mahasiswa angkatan 2015 (tahun masuk 2015). Di samping itu juga dilibatkan mahasiswa jurusan sejarah tingkat akhir yang sedang menulis proposal skripsi. Selain itu, data penelitian juga berasal data laporan akhir tugas kuliah.

Pegumpulan data penelitian mengenai kendala-kendala yang dialami mahasiswa dalam menulis proposal skripsi, penyebab munculnya kendala dan upaya mengatasi kendala tersebut diperoleh melalui wawancara khsusus dengan beberapa mahasiswa. Mahasiswa yang diwawancarai dipilih menggunakan teknik purposif, yakni sesuai dengan tujuan penelitian untuk memetakan kendala mahasiswa dalam menulis proposal skripsi. Mahasiswa yang diwawancarai diutamakan mahasiswa yang menghadapi kendala berat dilihat dari banyaknya kekeliruan merekamenulis proposal skripsi. Kekeliruan mahasiswa dalam menulis proposal skripsi diamati dari dokumenproposal skripsi yang mereka tulis. Oleh karena itu di samping melakukan wawancara, peneliti juga mengumpulkan data penelitian melalui pengamatan terhadap dokumen proposal skripsi mahasiswa. Peneliti melakukan observasi (pengamatan) terhadap detil penjelasan bab dan subbab proposal-proposal penelitian skripsi mahasiswa. Berdasarkan pengamatan tersebut peneliti mengidentifikasi kendala-kendala khusus yang dialami mahasiswa terkait dengan jenis penelitian yang akan merekalakukan, baik penelitian eksperimen, penelitian tindakan kelas (PTK) maupun jenis penelitian R\&D (Research and Development). Wawancara dengan mahasiswa yang sedang menulis proposal skripsi dimaksudkan untuk untuk memperoleh data-data yang tidak dapat dijangkau melalui pengamatan. Selain itu teknik dokumentasi juga dilakukan untuk memperoleh data-data visual berupa foto-foto untuk membuktikan kekeliruan yang dilakukan mahasiswa saat menulis proposal skripsi.

Dengan mencermati kekeliruan-kekeliruan mahasiswa menulis proposal penelitian dengan sendirinya juga memberikan data dan informasi mengenai ragam kendala yang dialami oleh mahasiswa dalam menulis proposal skripsi. Untuk menggali informasi lebih detil peneliti selanjutnya mewawancarai mahasiswa yang bersangkutan. Pada dasarnya penelitian ini dilakukan untuk memudahkan para mahasiswa jurusan sejarah mengatasi kendala yang dihadapi dalam penulisan proposal skripsi. 
Analisis data menggunakan model analisis interaktif yang dikembangkan oleh Milles \& Huberman. Langkah-langkah yang dilakukan dalam analisis data adalah sebagai berikut; 1)pengumpulan data, yaitu pengumpulan data dari hasil wawancara dan hasil observasiterhdapdokumen proposal skripsi, 2)reduksi data, merupakan suatu bentuk analisis untuk menajamkan, menggolongkan, mengarahkan, membuang data yang tidak perlu dan mengorganisasi data dengan cara sedemikian rupa sehingga ditemukanpolanya, 3) penyajian data, merupakan suatu rangkaian informasi yang memungkinkan untuk memperolah temuan penelitian, 4) penarikan kesimpulan, merupakan bagian verifikasi temuan penelitian (Ali Saukah, 2007).

\section{Hasil dan Pembahasan}

Menulis proposal penelitian skripsi adalah proses yang harus dilalui mahasiswa ketika akan menyelesaikan masa studi pada jenjang program sarjana. Tugas menulis proposal penelitian umumnya sudah dimulai saat mahasiswa mengambil mata kuliah metode penelitian. Tugas akhir mata kuliah adalah mahasiswa diminta menulis berbagai proposal menurut jenis penelitian tertentu. Meski demikian tugas menulis proposal penelitian skripsi bagi sebagian besar mahasiswa jurusan sejarah masih dirasakan sebagai tugas yang sulit. Mahasiswa sering terhalang menulis kerena menghadapi kendalakendala tertentu. Berikut dikemukakan temuan penelitian berkenaan dengan kendala-kendala yang dialami mahasiswa jurusan sejarah dalam menulis proposal skripsi.

Berdasarkan hasil analisis data ditemukan bahwa kendala-kendala yang dialami mahasiswa dalam proses penyusunan proposal skripsi umumnya bervariasi. Kendala utama yang dihadapi adalah kurangnya pemahaman mahasiswa mengenai struktur penulisan proposal yang sesuai dengan jenis penelitian yang diambil. Hasil wawancara dengan salah seorang mahasiswa, Rafi (2018) mengakui, "belum memahami secara keseluruhan struktur penulisan proposal ... kesalahan terletak pada diri saya, kurang menbaca contoh-contoh proposal...". Kendala berikutnya adalah sulit menemukan topik penelitian dengan ide-ide yang baru, menarik dan signifikan untuk diteliti. Di samping itu mahasiswa juga kurang terampil mengemukakan permasalahan dan merumuskan masalah penelitian. Kendala lain adalah kurangnya pemahaman mahasiswa mengenai kaidah penulisan karya tulis ilmiah dan menggunakan Bahasa Indonesia menurut EYD. Mahasiswa mengakui "Belum terlalu mahir dalam membuat tulisan yang sesuai dengan ejaan bahasa indonesia yang baik dan benar". 
Akibatnya tidak jarang mahasiswa sulit menuangkan ide-ide penelitian yang ada dalam pikirannya menggunakan bahasa ilmiah. Selain itu kendala lain saat menulis proposal skripsi yang dialami mahasiswa adalah menulis bagian latar belakang masalah terutama dalam memilih dan menggunakan kata dan penyusunan kalimat yang baik dan benar untuk menghubungkan satu paragraf dengan paragraf lainnya. Kurangnya pemahaman mahasiswa terhadap jenis-jenis metode penelitian pendidikan dan jenis teknik analisis data kuantitatif membuat mahasiswa sulit menentukan rumus yang tepat untuk menganalisis datayang selaras dengan permasalahan dan tujuan penelitian. Berikut dipaparkan kendala khusus yang dialami mahasiswa dalam menulis proposal skripsi menurut jenis penelitian.

Penelitian eksperimen (experimental research) adalah jenis penelitian yang berupaya mencari pengaruh variabel tertentu terhadap variabel lainnya dalam kondisi yang terkontrol secara ketat. Penelitian eksperimen merupakan penelitian yang dilakukan dengan melakukan manipulasi (perlakukan) yang bertujuan untuk mengetahui akibat pemberian perlakuantertentu terhadap perilaku individu yang diamati. Secara umum penelitian eksperimen adalah penelitian yang dilakukan untuk mengetahui pengaruh pemberian suatu perlakuan terhadap subjek penelitian.

Kendala utama mahasiswa dalam menulis proposal penelitian eksperimen berdasarkan pengamatan terhadap proposal yang mereka tulis dan hasil wawancara menunjukkan bahwa mahasiswa kurang memahami sistematika penulisan proposal penelitian eksperimen. Selain itu, berdasarkan hasil wawancara diketahui bahwamereka mengalami kendala menemukan kajian teori yang mendukung dan menunjukkan adanya hubungan antara variabel yang diteliti. Bagian ini termasuk dalam BAB II dalam proposal penelitian. Kendala ini pada akhirnya berdampak pada kekeliruan dalam membuat kerangka pikir penelitian. Kendala pada bagian ini terbukti dari kutipan hasil wawancara berikut dengan salah seorang mahasiswaEffendi, (2018):

Pada BAB ini (bab II) yang menyulitkan saya yaitu menyusun kerangka berfikir dan hipotesis. Sulit untuk memahami kerangka berfikir dan hipotesis walaupun jelas kerangka berfikir itu mengenai variabel-variabel pada penelitian namun saya masih sulit menentukan dan menghubungkan variabel-variabel itu sementara hipotesis merupakan kesimpulan awal yang dibuat dan menyakinkan bahwa penelitian kita akan menghasilkan sesuatu yang baru dan akan berhasil apabila dilakukan namun tetap menulitkan saya karena harus menghubungkan dan menganalisis ulang kajian teori serta kerangka berfikirnya”. 
Kendala yang dialami di awal penulisan proposal juga membawa dampak lanjutan saat memilih dan menetapkan desain eksperimen yang cocok dengan permasalahan dan tujuan penelitian serta karakteristik populasi dan sampel yang dilibatkan. Dari hasil pengamatan pada babmetode penelitian di proposal penelitian eksperimen yang ditulis oleh mahasiswa dan dari hasil wawancara ditemukan bahwa mahasiswa ternyata belum memahami dengan baik beragam jenis rancangan atau desain penelitian eksperimen. Berdasarkan pengakuan mahasiswa saat wawancara, ditemukan bahwa mahasiswa masih sulit membedakan desain pra-eksperimen, eksperimen semu, dan eksperimen murni. Mahasiswa masih banyak yang keliru menentukan jenis desain eksperimen yang akan mereka lakukan antara eksperimen murni atau eksperimen semu. Ini tercermin dari pengakuan mahasiswa Fakhriyani (2018), “Kendala yang saya alami ini karena kurangnya pengetahuan saya terhadap desain-desain penelitian eksperimen”.

Kendala lainnya berkenaan dengan cara pengambilan sampel yang mewakili populasi penelitian serta teknik analisis data. Hasil wawancara dengan mahasiswa diketahui bahwa mahasiswa belum terlalu memahami dan mendalami bagian teknik analisis data meski telah mengetahui jenis uji statistik yang digunakan, namun belum mereka belum tahu persis realisasi penggunaannya untuk menguji perbedaan atau hubungan antar variabel penelitian.

Penelitian Tindakan Kelas (PTK) adalah penelitian yang dilakukan guru dalam upaya mengatasi permasalahan yang muncul dalam proses pembelajaran. Tujuannya untuk meningkatkan mutu kegiatan pembelajaran melalui tindakan tertentu secara alamiah. Tindakan yang diambil hendaklah tindakan yang kreatif, efektif, efisien dan inovatifserta dilakukan secara berulang-ulang (siklus) untuk memastikan dampak (keberhasilan) tindakan yang dilakukan.

Kendala utama yang dialami mahasiswa dalam menulis proposal penelitian khususnya PTK tidak jauh berbeda dengan kendala menulis proposal untuk jenis penelitian eksperimen, yakni kurangnya pemahaman mahasiswa mengenai unsur-unsur PTK dan tergambar dari sistematika penulisan proposal PTK. Mahasiswa kurang terampil memadukan tahapan atau prosedur penelitian sesuai siklus PTK, terutama pada tahap perencanaan dan tahap tindakan. Salah seorang mahasiswa mengatakan,

"Kendala yang paling berarti bagi saya adalah ketidakpahaman untuk memadukan antara tahapan pada jenis penelitian dan prosedur penelitian, Belum terlalu memahami hal-hal yang harus dilakukan dalam setiap siklus dari prosedur penelitian". 
Kendala lain yang dialami oleh mahasiswa adalah sulit menentukan teknik pengumulan data dan analisis data sehingga mahasiswa bingung dalam mengolah data pada setiap tahapan siklus PTK. Salah seorang mahasiswa Putri (2018) menyatakan "Saya kurang paham dalam menentukan teknik pengumpulan data dan teknik analisis data penelitian tindakan kelas". Kondisi ini menunjukkan bahwa pemahaman mahasiswa dalam menulis proposal PTK di bagian subbab metode masih kurang dan memerlukan perhatian khusus baik oleh mahasiswa maupun oleh dosen yang mengajar mata kuliah metode penelitian pendidikan.

Research and development $(R \& D)$ merupakan penelitian yang terdiri dari rangkaian kegiatan untuk mengembangkan dan menghasilkan produk yang telah teruji memenuhi kebutuhan dan mengatasi permasalahan tertentu. Di bidang pendidikan R\&D dilakukan untuk memenuhi kebutuhan pendidikan sehingga produk yang dihasilkan adalah produk kependidikan, seperti bahan ajar, media pembelajaran dan lain sebagainya. Produk pendidikan yang dihasilkan bisa berupa produk yang baru maupun penyempurnaan dari produk yang telah ada sebelumnya. Kendala penulisan proposal R\&D oleh mahasiswa berdasarkan pengamatan terhadap proposal skripsi mereka adalah ketidakpahaman mengenai struktur penulisan proposal R\&D. Mahasiswa juga mengalami kendala sulitnya menemukan topik $R \& D$ yang benar-benar dibutuhkan oleh pengguna, unik dan mudah digunakan. Kendala lainnya berkenaan dengan caramerumuskan masalah yang sesuai dengan kondisi atau fenomena dilapangan. Mahasiswa juga kesulitan menuliskan spesifikasi produk yang diinginkan dan sesuai dengan kebutuhan pengguna. Spesifikasi produk adalah deskripsi detil tentang produk yangaka dikembangkan, mencakup bahan, ukuran, kualitas dan lain sebagainya (Sugiyono, 2016). Setelah diperiksa lebih lanjut ke bahagian kajian teori dan daftar pustaka, ditemukan bahwa mahasiswa tidak mampu menyajikan kajian teori yang relevan dan sesuai dengan kebutuhan penelitian. Setelah dikonfirmasi melalui wawancara dengan mahasiswa Yulia (2018) diketahui bahwa mehasiswa sulit menemukan sumber bacaan atau referensi yang relevan untuk menguraikan apa saja yang seharusnya ada dalam kajian teori terkait dengan jenis produk yang hendak dikembangkan. Hal ini juga dibuktikan dengan minimnya rujukan yang dipakai setelah diperiksa daftar pustaka dan refeensi yang digunakan mahasiswa.

\section{Simpulan}

Secara umum berdasarkan temuan penelitian dapat diperoleh kesimpulan bahwa mahasiswa prodi pendidikan sejarah mengalami berbagai 
kendala dalam menulis proposal penelitian menurut jenis penelitian. Kendala umum yang sangat dirasakan adalah kurangnya pemahaman mahasiswa mengenai karakteristik jenis penelitian pendidikan, diantaranya penelitian ekperimen, penelitian tindakan kelas dan penelitian pengembangan (R\&D). Perbedaan ciri khas jenis penelitian penelitian tersebut berkonsekuensi pada sistematika penulisan proposal penelitiannya. Umumnya mahasiswa mengalami kendala dalam menuliskan bab tiga (bab metode) penelitian karena masing-masing jenis penelitian eksperimen, PTK dan R\&D ada perbedaannya dalam menuliskan sub-subbabnya. Kendala penulisan proposal eksperimen antara lain berkenaan dengan penentuan desain penelitian, teknik pengambilan sampel dan teknik analisis data yang digunakan. Kendala penulisan proposal penelitian tindakan kelas bagi mahasiswa adalah kesulitan memadukan prosedur penelitian menurut siklus PTK serta kebingungan menentukan teknik pengumpulan dan analisis data. Sedangkan kendala penulisan proposal R\&D adalah kesulitan dalam menuliskan spesifikasi produk, menemukan referensi yang mendukung dan kurang memahami prosedur pengembangan sampai ke ujicoba produk.

\section{Daftar Rujukan}

Ali Saukah, D. (2007). Pedoman Penulisan Karya IImiah (edisi keempat). Universitas Negeri Malang.

Darmono, A., \& Hasan, A. (2002). Menyelesaikan skripsi dalam satu semester. Jakarta: Grasindo.

Effendi, A. R. (2018). Wawancara Mengenai Kendala yang Dihadapi Mahasiswa Jurusan Sejarahdalam Menulis Proposal Skripsi. Padang.

Fakhriyani, D. (2018). Wawancara Mengenai Kendala yang Dihadapi Mahasiswa Jurusan Sejarah dalam Menulis Proposal Skripsi. Padang.

Hadi, S. (2001). Metodologi research untuk penulisan paper, skripsi. Thesis dan Disertasi. Yogyakarta: Andi.

KBBI, T. P. (2008). Kamus Besar Bahasa Indonesia. Jakarta: Pusat Bahasa.

Muslich, M. (2010). Text book writing: Dasar-dasar pemahaman, penulisan, dan pemakaian buku teks. Jogjakarta: Ar-Ruzz Media, 52, 47-52. 
Muta'ali, L., Kinasih, S. S. K., \& Sumini. (2012). Daya Dukung Lingkungan untuk Perencanaan Pengembangan Wilayah. Badan Penerbit Fakultas Geografi (BPFG), Universitas Gadjah Mada.

Oruc, A. Y. (2012). Handbook of scientific proposal writing. Chapman and Hall/CRC.

Putri, R. H. (2018). Wawancara Mengenai Kendala yang Dihadapi Mahasiswa Jurusan Sejarah dalam Menulis Proposal Skripsi. Padang.

Rafi, M. (2018). Wawancara Mengenai Kendala yang Dihadapi Mahasiswa Jurusan Sejarahdalam Menulis Proposal Skripsi. Padang.

Sugiyono. (2016). Metode Penelitian dan Pengembangan untuk bidang pendidikan, manajemen,. bandung: Alfabeta.

Tan, S. T., Sidik, S. M., Rampal, L., Ibrahim, N., Tan, K. A., \& Ibrahim, Z. (2017). What Has Been Done to Tackle Overweight and Obesity in Malaysia?: A Literature Review (2005-2015). Pertanika Journal of Scholarly Research Reviews, 3(2).

Yulia, A. (2018). Wawancara Mengenai Kendala yang Dihadapi Mahasiswa Jurusan Sejarah dalam Menulis Proposan Skripsi. Padang. 